\title{
COPPER IN HOUSEHOLD DRINKING WATER IN THE CITY OF ZAGREB, CROATIA
}

\author{
Alica PIZENT and Sanja BUTKOVIĆ \\ Institute for Medical Research and Occupational Health, Zagreb, Croatia
}

Received in April 2010

Accepted in May 2010

\begin{abstract}
Copper concentration was estimated in tap water samples obtained from 70 households in Zagreb, serviced by a public water supply system. First-draw and flushed samples of tap water were collected in the morning and total copper concentration was determined by graphite furnace atomic absorption spectrometry with Zeeman-effect background correction. We also estimated the contribution of plumbing material to copper concentrations in tap water. In households with copper pipes, median and range copper values were $310 \mu \mathrm{g} \mathrm{L}^{-1}$ [(27 to 632) $\left.\mu \mathrm{g} \mathrm{L}^{-1}\right]$ in first-draw samples and $16 \mu \mathrm{g} \mathrm{L}^{-1}$ [(5 to 52) $\left.\mu \mathrm{g} \mathrm{L}^{-1}\right]$ in flushed samples. Corresponding values for households with galvanised pipes were $140 \mu \mathrm{g} \mathrm{L}^{-1}$ [(11 to 289) $\left.\mu \mathrm{g} \mathrm{L}^{-1}\right]$ and $8 \mu \mathrm{g} \mathrm{L}^{-1}$ [(1 to 42$) \mu \mathrm{g} \mathrm{L}^{-1}$, respectively. Copper concentrations in household tap water in Zagreb were far below the proposed safe limits set by the Croatian and WHO regulations and EPA standards, and drinking water in Zagreb is not a significant source of copper exposure.
\end{abstract}

KEY WORDS: copper concentration, flushing, GF AAS, tap water

Levels of copper found naturally in ground water and surface water are generally very low. Most copper contamination in drinking water is a result of corrosion of copper pipes or fittings. Copper is widely used for household plumbing and is normally resistant to corrosion. However, low $\mathrm{pH}$, high temperature, low total dissolved solids (TDS) content, and high amounts of dissolved oxygen or carbon dioxide can increase the leaching of copper into the water. Naturally soft water is more corrosive than hard water because it is more acidic and has low TDS.

According to the WHO recommendations (1) and current Croatian legislation (2), the maximum permissible concentration (MPC) for copper in drinking water is $2,000 \mu \mathrm{g} \mathrm{L}^{-1}$, whereas the maximum contaminant level regulated by the US Environmental Protection Agency (EPA) (3) for copper in ground and drinking water is $1,000 \mu \mathrm{g} \mathrm{L} \mathrm{L}^{-1}$.

Copper in drinking water in the concentration higher than $2,000 \mu \mathrm{g} \mathrm{L}^{-1}$ can cause a bitter metallic taste and result in blue-green stains on plumbing fixtures (4). Intake of elevated copper in drinking water can induce acute gastrointestinal symptoms, such as epigastric pain, nausea, vomiting, and diarrhoea (5).

Most household water supply lines in Croatia are made of galvanised steel, but the use of copper as plumbing material has increased over the last years. This article reports the concentrations of copper measured in drinking water in the households of the city of Zagreb and its surroundings.

\section{MATERIALS AND METHODS}

\section{Zagreb's water supply system}

The city of Zagreb, with a population of 850,000, lies on the alluvium of the Sava River. Water supply system uses groundwater from the aquifer composed 
of water-bearing sand and gravel stratum with clay layer on a surface $(6,7)$. Opened in 1878 , it is only five years younger than Vienna's water supply system, but five years older than the one in Munich.

Water quality in the water supply system has been controlled from 1879 in its physical and chemical aspects, and from 1888 in its bacteriological aspects. Results of water analysis in composed water samples for the five major pumping sites from 1 to 31 December 2009 indicate acceptable levels for all presented parameters (8). According to $\mathrm{pH}$ values, groundwater from Zagreb is neutral to slightly basic. Conductivity varies between $400 \mu \mathrm{S} \mathrm{cm}^{-1}$ and $1000 \mu \mathrm{S} \mathrm{cm}^{-1}$, and the groundwater temperature is $12^{\circ} \mathrm{C}$ to $17^{\circ} \mathrm{C}$. The content of oxygen dissolved in the water varies from $<1 \mathrm{mg} \mathrm{L}^{-1}$ to $10 \mathrm{mg} \mathrm{L}^{-1}$. Hardness is $13 \mathrm{dH}$ to $23 \mathrm{dH}$ $(7,8)$.

\section{Sampling and analysis}

Tap water samples were obtained from 70 households in Zagreb and surroundings serviced by the public water supply system. Two water samples were collected at each household in the morning. Fist-draw water sample was collected after the water has been allowed to stand in the pipes undisturbed overnight for at least six hours. The second, flushed water sample was collected after cold water had run from the kitchen faucet for two minutes. All samples were collected in acid-washed polyethylene containers. On arrival to the laboratory, each sample was preserved with concentrated suprapure nitric acid (Merck, Darmstadt, Germany) to obtain $\mathrm{pH}<2$ (total concentration of nitric acid was $1 \% \mathrm{~V} / \mathrm{V}$ ), and was kept refrigerated until analysis, for at least 24 hours.

Samples were obtained from the households of 70 employees of our Institute. They were asked to fill in a questionnaire and answer about plumbing material used for water pipes and the age of the building and water pipes.

Total copper in tap water was determined by graphite furnace atomic absorption spectrometry using a Perkin-Elmer AAnalyst 600 with a Zeeman background correction system. Samples were diluted five times in $1 \%(\mathrm{~V} / \mathrm{V}) \mathrm{HNO}_{3}$ and analysed by direct injection $(20 \mu \mathrm{L})$ into graphite furnace together with $5 \mu \mathrm{L}$ of matrix modifier containing $1.0 \mathrm{~g} \mathrm{~L}^{-1} \mathrm{Pd}$ (Merck) and $0.6 \mathrm{~g} \mathrm{~L}^{-1} \mathrm{Mg}\left(\mathrm{NO}_{3}\right)_{2}$ (Sigma-Aldrich, St Louis, MO, USA). All measurements were performed in triplicate. Measurement accuracy was controlled by analysing a NIST standard reference material no. $1643 \mathrm{~d}$ - Trace elements in water (National Institute of Standards and Technology, Gaithersburg, MA, USA) - with copper content of (22.76 \pm 0.31$) \mu \mathrm{g} \mathrm{L}^{-1}$. The mean and standard deviation of our measurement was $(22.54 \pm 0.22) \mu \mathrm{g} \mathrm{L}^{-1}$. The precision of the method, expressed as relative standard deviation (RSD) and calculated on the basis of seven replicates of the SRM $1643 \mathrm{~d}$ sample, was $6 \%$ when measured on the same day (within-day precision) and $8 \%$ when measured on different days (day-to-day precision). The recovery of the method, calculated on the basis of measurement of the SRM 1643d samples spiked with $25 \mu \mathrm{g} \mathrm{L} \mathrm{L}^{-1}, 50 \mu \mathrm{g} \mathrm{L}^{-1}, 80 \mu \mathrm{g} \mathrm{L}{ }^{-1}$, and $100 \mu \mathrm{g} \mathrm{L}{ }^{-1}$, was $(98 \pm 3) \%$ (range: $95 \%$ to $103 \%$ ). The average characteristic mass of copper obtained by measuring 140 water samples was $16.71 \mathrm{pg}$, which is in very good agreement with the theoretical result of $(17 \pm 3.4) \mathrm{pg}$, declared by the manufacturer.

\section{Statistics}

Due to a small number of samples, copper concentration in drinking water was not normally distributed and the results were presented as median and range. The significance of the difference in copper concentrations between copper and galvanised pipes and between first-draw and flushed water samples was calculated using the Mann-Whitney U-test (Z, p). We used Spearman rank regression analysis to estimate the association between the copper concentration in drinking water and the age of water pipes.

\section{RESULTS AND DISCUSSION}

Table 1 shows the range, the $10^{\text {th }}, 25^{\text {th }}, 50^{\text {th }}$ (median), $75^{\text {th }}$, and $90^{\text {th }}$ percentile values for copper in the first-draw and flushed samples of drinking water, regardless of material used for plumbing. The highest overall copper levels were found in the first-draw water samples that had been standing in pipes all night. Our results have confirmed that flushing the pipes before using the tap water significantly reduces copper concentration in drinking water (Mann-Whitney Utest: $\mathrm{Z}=9.771, \mathrm{p}<0.0001$ ).

In households with copper pipes, median and range copper values in first-draw samples were $310 \mu \mathrm{g} \mathrm{L}^{-1}$ [(27 to 632) $\left.\mu \mathrm{g} \mathrm{L}^{-1}\right]$, whereas in households with galvanised pipes they were $140 \mu \mathrm{g} \mathrm{L}^{-1}$ [(11 to 289) $\mu \mathrm{g} \mathrm{L}^{-1}$ ] (Mann-Whitney U-test: $\mathrm{Z}=2.173$, $\mathrm{p}=0.03)$. Corresponding copper values in flushed samples were $16 \mu \mathrm{g} \mathrm{L}^{-1}$ [(5 to 52) $\left.\mu \mathrm{g} \mathrm{L}^{-1}\right]$ and $8 \mu \mathrm{g} \mathrm{L}^{-1}$ 
[(1 to 42$) \mu \mathrm{g} \mathrm{L}^{-1}$ ], respectively (Mann-Whitney Utest: $\mathrm{Z}=3.315, \mathrm{p}=0.001)$. The decrease in copper concentration in first-draw water samples from copper pipes with age was not statistically significant $(R=-$ $0.575, \mathrm{p}=0.082$ ), probably due to a small number of households with copper pipes $(\mathrm{N}=10)$.

Table 1 Copper concentration in drinking water of 70 households in the city of Zagreb and surroundings (Croatia)

\begin{tabular}{|c|c|c|}
\hline & 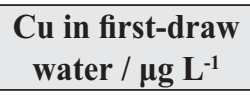 & $\begin{array}{l}\mathrm{Cu} \text { in flushed } \\
\text { water / } \mu \mathrm{g} \mathrm{L}^{-1}\end{array}$ \\
\hline Range & 11 to 632 & 1 to 52 \\
\hline \multicolumn{3}{|c|}{ Percentile } \\
\hline $10^{\text {th }}$ & 44 & 5 \\
\hline $25^{\text {th }}$ & 97 & 6 \\
\hline $50^{\text {th }}$ & 197 & 10 \\
\hline $75^{\text {th }}$ & 285 & 15 \\
\hline $90^{\text {th }}$ & 433 & 26 \\
\hline
\end{tabular}

The concentration of copper in the tap water in Croatia was also measured by Fiket et al. (9). However, they measured copper and other trace elements in only three samples from Zagreb and one sample from Rijeka after water was flushed for 2 minutes. Median copper value for the means of triplicates measured in samples from Zagreb was $10.52 \mu \mathrm{g} \mathrm{L}^{-1}$. Concentration of copper in sample from Rijeka was $1.67 \mu \mathrm{g} \mathrm{L}^{-1}$. Authors did not measure copper in the first-draw water samples nor did they report the material used for plumbing.

Our results are similar to data reported for several European cities (10): mean copper levels obtained in the first-draw water samples were $30 \mu \mathrm{g} \mathrm{L}^{-1}$ in Mannheim, Germany, $20 \mu \mathrm{g} \mathrm{L}^{-1}$ in Nancy, France, $190 \mu \mathrm{g} \mathrm{L}^{-1}$ in Breda, the Netherlands, and $30 \mu \mathrm{g} \mathrm{L}^{-1}$ in Athens, Greece and Dublin, Ireland. Geometric mean and $95 \%$ confidence interval for copper concentration in drinking water that had been standing in pipes over night in Krakow, Poland was $8 \mu \mathrm{g} \mathrm{L}{ }^{-1}$ [( 1 to 110) $\left.\mu \mathrm{g} \mathrm{L}^{-1}\right]$ (11). In another study from Germany, mean copper concentration was $183 \mu \mathrm{g} \mathrm{L}^{-1}$ in 1619 stagnated water samples and $106 \mu \mathrm{g} \mathrm{L}^{-1}$ in 1660 random daytime samples (12). The highest median copper concentration of $930 \mu \mathrm{g} \mathrm{L}^{-1}$ in the first-draw water samples was reported by Scandinavian authors (13). After flushing for $30 \mathrm{~s}$ copper concentration decreased to $190 \mu \mathrm{g} \mathrm{L}^{-1}$ and after flushing until the water ran consistently cold the concentration dropped to $80 \mu \mathrm{g} \mathrm{L}^{-1}$. A median copper concentration of $260 \mu \mathrm{g} \mathrm{L}^{-1}$ in stagnated drinking water from drinking water fountains in 50 schools in the state of New
Jersey, USA, decreased to $68 \mu \mathrm{g} \mathrm{L}^{-1}$ after $10 \mathrm{~min}$ of flushing in the morning, but levels increased by lunchtime to $120 \mu \mathrm{g} \mathrm{L} \mathrm{L}^{-1}$ (14).

Our results have shown that drinking water contributes only marginally to copper intake. An average person who drinks eight glasses of water (1.6 L) with copper in the concentration of $1 \mu \mathrm{g} \mathrm{L} \mathrm{L}^{-1}$ to $52 \mu \mathrm{g} \mathrm{L}^{-1}$ found in flushed samples in our study would have a daily copper intake from tap water of $1.6 \mu \mathrm{g}$ to $83.2 \mu \mathrm{g}$. Taking into account the highest copper concentration found in the first-draw water samples $\left(632 \mu \mathrm{g} \mathrm{L}^{-1}\right)$ and sample volume of $0.2 \mathrm{~L}$ to $0.4 \mathrm{~L}$ that was typically drank in the morning (as coffee or tea), daily intake of copper would be $4.4 \mu \mathrm{g}$ to $252.8 \mu \mathrm{g}$. This is much lower than the recommended dietary allowance (RDA) of $900 \mu \mathrm{g} \mathrm{d}^{-1}$ for adults (15).

In conclusion, all tested samples had lower copper concentrations than the current Croatian (2), WHO (1), and EPA (3) water standards. Drinking water in Zagreb is not a significant source of copper exposure.

\section{REFERENCES}

1. World Health Organization (WHO). Guidelines for Drinking Water Quality. $3^{\text {rd }}$ ed. Geneva: WHO; 2004.

2. Pravilnik o zdravstvenoj ispravnosti vode za piće [Regulations on health safety of drinking water, in Croatian]. Narodne Novine 47/2008.

3. US Environmental Protection Agency (US EPA). Drinking water standards. Washington (DC): Office of Drinking Water; 2003.

4. Edwards M, Ferguson JF, Reiber SH. The pitting corrosion of copper. J Am Water Works Assoc 1994;86:74-90.

5. Pizarro F, Olivares M, Gidi V, Araya M. The gastrointestinal tract and acute effects of copper in drinking water and beverages. Rev Environ Health 1999;14:231-8.

6. Tedeschi S. Surface and groundwater use in the urban area of Zagreb. In: Massing H, Packman J, Zuidema FC, editors. Proceedings of the International Symposium Hydrological Processes and Water Management in Urban Areas; 24-29 April 1988. Duisburg, Germany. Wallingford, Oxfordshire: IAHS; 1990. Publication No. 198. p. 95-9.

7. Brkić Ž, Kapelj S, Larva O, Marković T, Vlahović T. Hydrogeology and hydrogeochemistry in the alluvial aquifer of the Zagreb area (Croatia). RMZ - Materials and Geoenvironment 2003;50:75-8.

8. Zagrebački holding, podružnica vodoopskrba i odvodnja. Tablica kvalitete vode [displayed 15 April 2010]. Available at http://www.vio.hr/default.aspx?id=44.

9. Fiket Ž, Roje V, Mikac N, Kniewald G. Determination of arsenic and other trace elements in bottled waters by high resolution inductively coupled plasma mass spectrometry. Croat Chem Acta 2007;80:91-100.

10. Sadhra SS, Wheatley AD, Cross HJ. Dietary exposure to copper in the European Union and its assessment for EU regulatory risk assessment. Sci Total Environ 2007;374:223-34. 
11. Barton H. Predicted intake of trace elements and minerals via household drinking water by 6-year-old children from Krakow (Poland). Part 4: Copper. Food Addit Contam Part A Chem Anal Control Expo Risk Assess 2009;26:988-1001.

12. Zietz B P, Dassel De Vergara J, Dunkelberg H. Copper concentrations in tap water and possible effects on infant's health - Results of a study in Lower Saxony, Germany. Environ Res 2003;92:129-38.

13. Pettersson R, Rasmussen F. Daily intake of copper from drinking water among young children in Sweden. Environ Health Perspect 1999;107:441-6.
14. Murphy EA. Effectiveness of flushing on reducing lead and copper levels in school drinking water. Environ Health Perspect 1993;101:240-1.

15. Food and Nutrition Board, Institute of Medicine. Dietary Reference Intakes for Vitamin A, Vitamin K, Arsenic, Boron, Chromium, Copper, Iodine, Iron, Manganese, Molybdenum, Nickel, Silicon, Vanadium, and Zinc. Washington (DC): National Academy Press; 2001. 


\section{Sažetak}

\section{BAKAR U PITKOJ VODI KUĆANSTAVA GRADA ZAGREBA}

Koncentracija bakra u pitkoj vodi određena je u 70 kućanstava grada Zagreba koja su priključena na gradski vodovod. U svakom kućanstvu uzeta su po dva uzorka pitke vode: uzorak vode uzet iz slavine odmah ujutro nakon stajanja vode u vodovodnoj cijevi tijekom noći, tj. najmanje šest sati, te uzorak vode uzet iz iste slavine nakon što je voda puštena da teče dvije minute. Ukupna koncentracija bakra određena je elektrotermičkom atomskom apsorpcijskom spektrometrijom uz Zeemanovu korekciju nespecifične apsorpcije. Osim toga, ispitan je utjecaj materijala od kojeg su izrađene vodovodne cijevi na koncentraciju bakra u pitkoj vodi. U kućanstvima s bakrenim cijevima, vrijednosti medijana i raspona bakra bile su $310 \mu \mathrm{g} \mathrm{L}^{-1}$ [(27 do 632) $\mathrm{g} \mathrm{L}^{-1}$ ] u uzorcima pitke vode koja je stajala u cijevima tijekom noći, te $16 \mu \mathrm{g} \mathrm{L}^{-1}$ [(5 do 52) $\mu \mathrm{g} \mathrm{L}^{-1}$ ] u uzorcima vode uzetim nakon isplahnjivanja cijevi. Odgovarajuće vrijednosti bakra dobivene u kućanstvima s galvaniziranim cijevima bile su $140 \mu \mathrm{g} \mathrm{L}^{-1}\left[(11\right.$ do 289$) \mu \mathrm{g} \mathrm{L}^{-1}$, odnosno $8 \mu \mathrm{g} \mathrm{L}^{-1}$ [(1 do 42) $\mu \mathrm{g} \mathrm{L}^{-1}$. Rezultati pokazuju da su koncentracije bakra izmjerene u pitkoj vodi kućanstava grada Zagreba znatno niže od predloženih graničnih vrijednosti propisanih hrvatskim, WHO i EPA-standardima. Bakar u pitkoj vodi grada Zagreba nije značajan izvor izloženosti bakru.

KLJUČNE RIJEČI: ET AAS, isplahnjivanje cijevi, koncentracija bakra, pitka voda

\section{CORRESPONDING AUTHOR:}

Alica Pizent

Analytical Toxicology and Mineral Metabolism Unit Institute for Medical Research and Occupational Health Ksaverska cesta 2, HR-10001 Zagreb, Croatia E-mail:apizent@imi.hr 